\title{
組換えインフルエンザウイルスの構築と応用
}

\section{特集 組換えウイルスキャリア一遺伝子治療・ワクチン応用への新展開一}

\section{村上 晋・堀本泰介 $\cdot$ 河岡義裕 ${ }^{*}$}

Construction and application of the recombinant influenza viruses

Recently established reverse genetics of influenza virus allows us to generate the recombinant viruses with arbitrarily modified viral proteins. The recombinant viruses are now utilized as useful tools in basic research fields. Moreover, in application, H5N1 pre-pandemic vaccines, which are now stockpiled in many countries, were generated by using the reverse genetics to attenuate the virus. In the future, the technology of reverse genetics will contribute us to develop the next generation of influenza vaccines. On the other hand, construction of the recombinant viruses that express foreign proteins, epitopes, or genes may lead to application for multivalent vaccines inducing effective immune responses and vectors for gene therapy. A variety of such approaches are now in underway to exploit recombinant viruses for practical use.

インフルエンザウイルスのリバースジェネティクスの確立により， ウイルス蛋白質を任意に改変し た変異ウイルスの作製が可能になった．そういった変異ウイルスは，現在のインフルエンザの基礎研 究において久かすことのできない有用なツールとして活用されている．また，応用面においても，現 在備蓄が進んでいる H5N1 プレパンデミックワクチンには本法を用いて作製された弱毒変異ウイル スが用いられている．今後，変異ウイルス作製技術は，インフルエンザの次世代ワクチンの開発にも 大いに貢献することが期待される.

一方，リバースジェネティクスを用いた外来性エピトープや外来性遺伝子を発現する組換えインフ ルエンザウイルスの構築により，効果的な免疫応答を惹起する多価ワクチンや遺伝子治療用デリバ リーベクターへの応用が考えられている．現時点では，組換えウイルスの安定性，発現性，増殖性な どの問題点を改善する必要性が指摘されているものの, インフルエンザウイルスベクターの持つ数多 くの利点を活かすべく実用化を目指したさまざまなアプローチが展開されている.

Shin Murakami • Taisuke Horimoto • Yoshihiro Kawaoka* key words : Influenza virus, reverse genetics, virus vector, vaccine

遺伝子治療用ベクターやワクチンベクターにとっ て, 遺伝子導入効率と安定した遺伝子発現は重要な 要素である. 効率的な遺伝子導入のために, これま でにアデノウイルス，レトロウイルスなどをベース としたウイルスベクターがさまざまな目的で開発さ れ, 臨床試験段階にある ${ }^{1)}$. インフルエンザウイル スもそのベクターとしての応用性を模索するため, 実験室レベルで精力的に研究されているが, 実際に 臨床試験にまで到達した事例はない. しかしなが ら，インフルエンザウイルスベクターは，他のウイ ルスベクターと比較しても, 安全性あるいは有効性 などにおいて以下のような大いに期待できる特徴が

\footnotetext{
* Division of Virology, Department of Microbiology and Immunology, Institute of Medical Science, University of Tokyo 東京大学医 科学研究所・ウイルス感染分野
}

ある、

(1) 複製にDNA ステップがないのでウイルスゲ ノムが宿主染色体に取り込まれるおそれがなく宿主 に対する変異原性, 腫瘍原性がないこと

(2) 持続感染や潜伏感染がなく, また有効な抗ウ イルス薬が使用できるためべクターウイルスを確実 に制御できること

(3)ヒトに病原性がない弱毒ウイルス $(\mathrm{FDA} く ア$ メリカ食品医薬局〉認可生ワクチンウイルスを含む） が利用できること といった点から非常に高い安全性が見达まれる。ま た，有効性に関しても，

(4) 確実に呼吸器上皮細胞に感染し, また初期免 疫反応を強く誘導すること

(5)それ自体が抗原提示細胞(未成熟樹状細胞や 


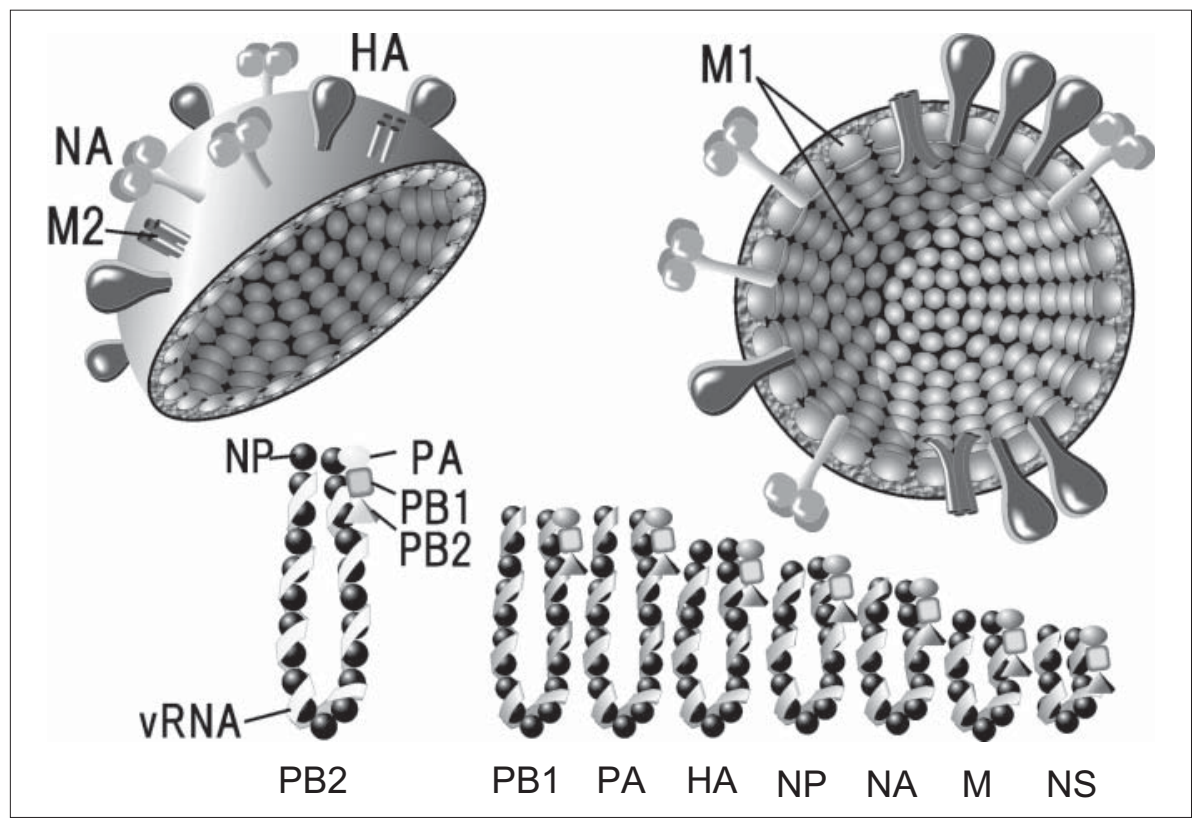

図 1

$\mathrm{A}$ 型インフルエンザウイルスの 粒子とゲノム インフルエンザウイルス粒子内 に8 種類のゲノム分節が存在し ている.
単球など)に効率よく感染することから発現する分 子による防御効果との相乗効果が期待できること

6 インフルエンザ抗体保有者においてはべク ターのヘマグルチニン (HA：赤血球凝集素)亜型の 選択によりその感染効率を操作することが可能であ ること

などの特徴から非常に期待できるものである.さら に,

(7) 発育鶏卵や培養細胞を用いて高力価のストッ クウイルスが用意できること

は経済性にすぐれる利点である。これらの特徴に加 えて

8 プラスミドベースのリバースジェネティクス の開発

9 インフルエンザウイルスゲノムのパッケージ ングシグナルの同定により, 従来にくらべてより容 易にそしてより効率的に外来遺伝子を搭載したウイ ルスを作製できるようになってきた。

これらの利点を発揮すべく, 現在, インフルエン ザベクターの臨床応用を目指した開発研究が精力的 に行われている。本稿では，これまでに報告されて いる組換えインフルエンザウイルスの概要について ワクチンウイルスを含め概説する.

\section{インフルエンザウイルス}

A 型インフルエンザウイルスはオルソミクソウ イルス科に属し，マイナス鎖 RNAをゲノムとして 持つエンベロープウイルスである. ヒトインフルエ ンザウイルスは内部蛋白質の抗原性が異なる B 型, $\mathrm{C}$ 型も知られているが，世界的大流行(パンデミッ ク)の原因となるのは A 型ウイルスである.

A 型ウイルスは 8 本に分節化された RNA をゲノ ムとし，少なくとも 11 種類の蛋白質がコードされ ている(図 1)．分節状 RNA のうち長い 3 本の RNA 分節がウイルスポリメラーゼのサブユニット (PB2, PB1，およびPA)をコードしている。この三つのサ ブユニットからなるポリメラーゼはウイルス RNA (vRNA)をメッセンジャーRNA（mRNA）に転写, あるいは自身のvRNA を複製する働きをもつ RNA 依存性 RNA ポリメラーゼで, 核蛋白質 (NP) とと もにvRNAに結合しリボ核蛋白質複合体(RNP 複 合体)を形成する.

ウイルスの表面にある HA とノイラミニダーゼ (NA) はそれぞれ HA 分節，NA 分節にコードされ る. HA は細胞のシアル酸を末端に持つ糖鎖をレセ プターとして認識し，またエンベロープとエンド ソーム膜との融合能を有する. NA はウイルスが感 染細胞から放出されるときに細胞表面のシアル酸を 


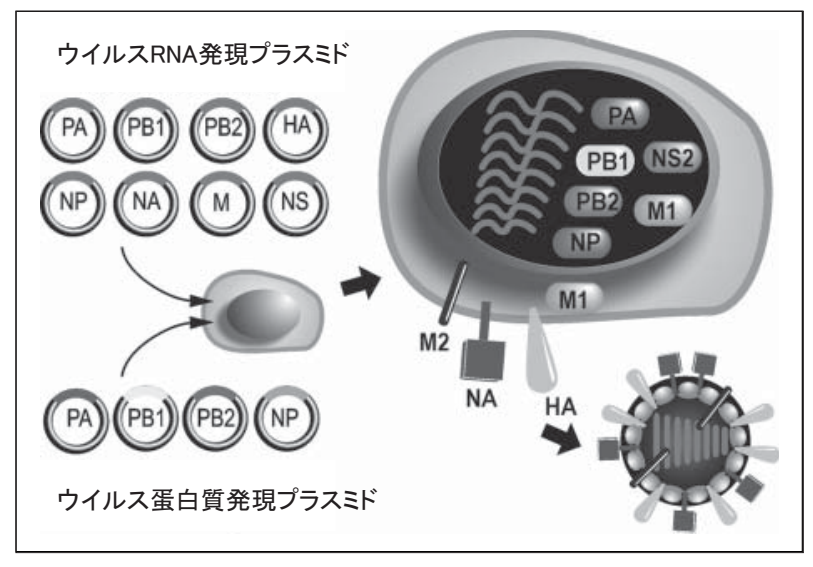

図 2 リバースジェネティクスによる組換えインフルェン ザウイルスの作製

ウイルス遺伝子分節を合成するプラスミドを 8 種類用意す る. 目的の遺伝子に改変や変異を導入することが可能であ る.これに加えてウイルス遺伝子分節の転写・複製に必要 な蛋白質 $(\mathrm{PB} 2, \mathrm{~PB} 1, \mathrm{PA}$, と $\mathrm{NP})$ を発現する 4 種類のプラ スミドを用意する。

合計 12 種類のプラスミドを $293 \mathrm{~T}$ 細胞等に導入すると, 培 養上清に組換えウイルスが回収される.

切断し, ウイルス粒子の放出を促す.

$\mathrm{M}$ 分節には M1 と mRNAのスプライシングに よって産生される M2 の二つの蛋白質がコードされ ている. M1 はエンベロープの裏打ち構造を形成す る. M2 はイオンチャネルとして働き, 感染初期に エンドソームに扔けるウイルス粒子内の $\mathrm{pH}$ を低下 させ, $\mathrm{RNP}$ 複合体の細胞内への放出 (脱殼)を促進 する.

NS 分節も NS1 蛋白質と mRNA のスプライシン グによって産生される NS2/NEP 蛋白質をコードし ている. NS1 は多機能であるが, 特にインターフェ ロンのアンタゴニストとしての働きが知られる。一 方, NS2/NEP は新しく合成された RNP 複合体の 核外輸送に関わっている。

\section{リバースジェネティクスの開発}

1989 年に外来遺伝子を導入した組換えインフル エンザウイルスの作製がはじめて報告された ${ }^{2)}$ 、レ ポーター(CAT) 遺伝子を NS 分節の 3 と 5 末端の非 コード領域の間に挿入した組換え DNA を T7 プロ モーターによって in vitro で転写した組換え RNA 分子を, ウイルスから精製したポリメラーゼおよび
$\mathrm{NP}$ と反応させ RNP 複合体が作製された，それを ヘルパーウイルスを感染させた細胞にトランスフェ クトすると, ヘルパーウイルスのポリメラーゼに よって CAT 遺伝子を持つ組換え RNA が複製し, その結果, ウイルス粒子に RNA 分節の一つとして パッケージングされた。しかし，この組換えウイル スの CAT 遺伝子分節は, 数回の継代により脱落し た.

このようにヘルパーウイルスを用いる初期のリ バースジェネティクス (RNP トランスフェクション 法) は, 操作が煩雑なうえに変異ウイルスの選択手 段が限られていたため任意のウイルス遺伝子を操作 することは不可能であった.

これを一気に解決したのが 1999 年に筆者らが開 発したヘルパーウイルスを必要としないプラスミド ベースのリバースジェネティクス(プラスミドトラ ンスフェクション法)である3,4).これによってウイ ルス遺伝子を持つプラスミドから改変された任意の 組換えウイルスを効率よく作製することが可能に なった。

プラスミドトランスフェクション法は, ヒト RNA ポリメラーゼI(Poll) プロモーターの制御に よって 8 種類のウイルス RNA 発現させる 8 個のプ ラスミドと, 転写, 複製を制御する 4 種類のウイル ス蛋白質 $(\mathrm{PA}, \mathrm{PB} 1, \mathrm{~PB} 2$ と NP) を発現する 4 個の プラスミドの計 12 個のプラスミドを細胞に同時に トランスフェクトすることによって, ウイルスを作 製する方法である(図 2).

この方法によって, 導入した変異がウイルスに とって致命的ではない限り任意の変異をウイルスに 導入できる. その後, いくつかの変法や改良が加え られ，より効率的なウイルス産生が可能となった. たとえば, PolI による RNA 発現ユニットを挟み込 むようにRNA ポリメラーゼII (Pol II ) とポリ A シ グナルを付加したプラスミドを用いて，一つのプラ スミドからウイルス遺伝子とウイルス蛋白質を発現 させる方法により，8個のプラスミドのトランス フェクトにより変異ウイルスを作製することも可能 になった5).

また, ウイルス RNA 発現のための PolI 転写ユ ニットを 8 個連結させたプラスミドの利用により, 
表 1 HA 蛋白質に挿入された外来遺伝子を発現する組換えインフルエンザウイルス

\begin{tabular}{l|c|c|l}
\hline \multicolumn{1}{c|}{ 外来遺伝子 } & 挿入アミノ酸残基数 & 抗原部位 & \multicolumn{1}{|c}{ 参支献 } \\
\hline Plasmodium yoelii スポロゾイト周囲蛋白質 & 12 & $\mathrm{~B}$ & $37)$ \\
HIV-1 gp120 & 12 & $\mathrm{~B}$ & $38,39)$ \\
HIV-1 gp41 & 7 & $\mathrm{~B}$ & $40,41)$ \\
HIV-1 gp41 & 8 & $\mathrm{~B}$ & $41)$ \\
Plasmodium falciparum スポロゾイト周囲蛋白質 & 12 & $\mathrm{~B}$ & $13)$ \\
ß-galactosidase & 9 & $\mathrm{~B}$ & $12)$ \\
HIV-1 gp120 & 12 & $\mathrm{~B}$ & $39,42)$ \\
Pseudomonas aeruginosa $\mathrm{F}$ & 11 & $\mathrm{~B}$ & $43)$ \\
オボアルブミン & 17 & $\mathrm{~B}$ & $44)$ \\
Influenza NP & 9 & $\mathrm{E}$ & $45)$ \\
Plasmodium yoelii スポロゾイト周囲蛋白質 & 12 & $\mathrm{E}$ & $37,38,46)$ \\
\hline
\end{tabular}

トランスフェクトするプラスミド数を 3 個 (蛋白質 発現プラスミドは 2 個を含む)にまで減少させるこ とで,ささら効率のよいウイルス産生も可能となっ た6).さらに, 効率はわるいものの, PolII プロモー ター(T7)の制御でウイルス RNA を発現させる系 や7)，アデノウイルスベクターを利用した系なども 報告されている.

このように開発されたインフルエンザウイルスの リバースジェネテイクス系は，それぞれの目的に応 じて使いわけられている.

\section{外来性抗原エピトープや蛋白質を発現する 組換えインフルエンザウイルス}

$$
\text { リバースジェネティクス (RNPトランスフェク }
$$
ション法あるいはプラスミドトランスフェクション 法)の開発によって, 外来性エピトープや外来性蛋 白質を持ったインフルエンザウイルスの作製が可能 になった。

これまでに, (1) HA や NA に外来性抗原エピトー プを挿入したウイルス, (2) 追加の分節(9本目)に 外来遺伝子を搭載し発現させるウイルス, (3) ウイ ルス蛋白質と外来性蛋白質を融合させ発現させるウ イルス, (4) 外来性蛋白質をコードする遺伝子とウ イルス遺伝子を bicistronic に一つの RNA 分節から 発現させるウイルスなどが作製されている.

さらに, インフルエンザウイルスのゲノムパッ ケージング配列の同定によって, より効率的に外来 性遺伝子を取り込ませたウイルスの作製が可能と なった。いくつかの報告例について記載したい.

\section{HA 分節に外来性遺伝子を挿入した 組換えインフルエンザウイルス}

インフルエンザウイルスに感染した宿主では多く の抗体がHAに対して産生される.したがって, 特異的な B 細胞エピトープ応答を効率よく誘導す るために, 外来性ペプチド配列を HA の抗原部位 に挿入した組換えウイルスが作製された。 HA 上の 抗原部位は 5 領域 $(\mathrm{A}, \mathrm{B}, \mathrm{C}, \mathrm{D}$ と $\mathrm{E})$ 同定されて いるが，そのうち B あるいは $\mathrm{E}$ 領域に外来性抗原 エピトープを挿入した組換えウイルスの作出に成功 している(表 1). 加えて, 動物実験レベルでは, こ れらの組換えウイルス感染によってそれぞれの導入 したエピトープに対する免疫反応の誘導も確認され ている. また, $\mathrm{T}$ 細胞エピトープを抗原部位 $\mathrm{E} に$ 挿入した組換えウイルスでは感染宿主内で細胞傷害 性 T 細胞 (CTL) 応答が観察されている.

ペプチド(抗原エピトープ)の挿入に加えて，より 分子量の大きなポリペプチドを HA に挿入した増 殖可能な組換えウイルスについても報告されてい

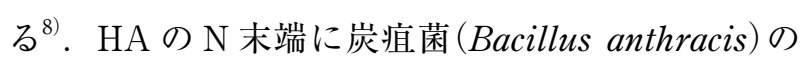
PA ドメイン 1'(致死浮腫因子：90アミノ酸残基) あ るいは PAのドメイン 4(レセプター結合部位； 140 アミノ酸残基)を挿入した組換えウイルスは, 野生 型のウイルスに匹敵する増殖性を示し，また挿入し た遺伝子は数回の継代を経ても安定に維持された. そして,このウイルスで免疫したマウスは炭疽を効 果的に防御した。 
表 2 NAのストーク領域に組み込まれた外来遺伝子を発現する組換えインフルエンザウイルス

\begin{tabular}{|c|c|c|}
\hline 外来遺伝子 & 挿入アミノ酸残基数 & 参考文献 \\
\hline Flag エピトープ & 8 & 47) \\
\hline Plasmodium yoelii スポロゾイト周囲蛋白質 & 9 & 37) \\
\hline Plasmodium yoelii スポロゾイト周囲蛋白質 & 9 & 48) \\
\hline リンパ球性脈絡髄膜炎ウイルス (LCMV)NP & 12 & 49) \\
\hline 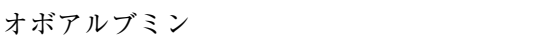 & 8 & $50)$ \\
\hline E75 HER-2 KIF & 9 & $51)$ \\
\hline Chlamydia trachomatis 主要外膜蛋白質 & 12 & $52)$ \\
\hline$\beta$-galactosidase & 9 & 12) \\
\hline $\mathrm{HSV}-1 \mathrm{gB}$ & 8 & $50,53)$ \\
\hline HSV-1 RR & 8 & $50)$ \\
\hline influenza NP & 9 & $50)$ \\
\hline
\end{tabular}

表 3 NA 遺伝子に組み込まれた外来遺伝子を発現する組換えインフルエンザウイルス

\begin{tabular}{l|l|l}
\hline \multicolumn{1}{c|}{ 外来遺伝子 } & \multicolumn{1}{|c}{ 戦 略 } & \multicolumn{1}{|c}{ 考文献 } \\
\hline CAT & 口蹄疫ウイルス 2A & $11,16)$ \\
SIV Gag & 口蹄疫ウイルス 2A & $14)$ \\
SIV Gag & 口蹄疫ウイルス 2A & $15)$ \\
Plasmodium yoelii スポロゾイト周囲蛋白質 & IRES(BIP) & $13)$ \\
$\beta$-galactosidase & IRES(BIP) & $12)$ \\
CAT & IRES(BIP) & $11)$ \\
HIV-1 Gp41 & IRES(BIP) & $11)$ \\
VP0 Mengo virus & 内在性プロモーター & $9)$ \\
CAT & 内在性プロモーター & $9)$ \\
GFP & 内在性プロモーター & $10)$ \\
\hline
\end{tabular}

\section{NA 分節に外来遺伝子を挿入した 組換えインフルエンザウイルス}

NA は一般にマッシュルーム型の構造をとり， NA 活性ドメインはその頭部領域に存在する。した がって，NA 機能に影響しないストーク領域に外来 性ペプチド配列を挿入する試みがいくつか報告され ている.

そのなかでも主に T 細胞エピトープを導入した 組換えウイルスの例を表 2 に示した。病原体に対し て有効なワクチンは液性免疫だけではなく細胞性免 疫も必要とされるが，この方法によって防御免疫を 誘導することが可能であった。 また，外来性抗原の エピトープのみならず遺伝子レベルの NA 分節へ の挿入もいくつかの組換えウイルスで報告されてい る(表 3). その場合, 主に三つの戦略によって外来 遺伝子の挿入が行われている.

一つ目はNA 遺伝子の下流にウイルスプロモー ター配列 (3’非翻訳領域)を導入し, それを内部プロ モーターとしてその下流の外来性遺伝子を bicistronic に発現させる方法である ${ }^{10)}$.
二つ目は bicistronic な遺伝子 (NA 遺伝子と外来 性遺伝子)をヒト免疫グロブリン重鎖結合蛋白質 (Bip) 由来の internal ribosomal entry site (IRES) で連結し発現させる方法である ${ }^{13)}$. IRES 配列を 持った RNA は cap 非依存的に ORF が翻訳される ことから, NA と外来性遺伝子を一本の RNA から 発現させることができる.

三つ目には口蹄疫ウイルス由来の $2 \mathrm{~A}$ 蛋白質認識 配列(FMD 2A) $\mathrm{NA}$ と外来性蛋白質の間に挿入 する方法である ${ }^{16)}$ 。この認識配列によって外来性蛋 白質がウイルス蛋白質から切断される.

\section{NS 分節に外来遺伝子を挿入した 組換えインフルエンザウイルス}

つぎに, NS 分節に外来性遺伝子を挿入した例を 紹介する(表 4)。インフルエンザウイルスの NS1 蛋白質はI 型インターフェロンのアンタゴニストの 機能を持つ蛋白質である. 外来性遺伝子配列を NS 分節に抻入して発現させることは実用的なアプロー チであると考えられる。つまり， 
表 4 NS 遺伝子に組み込まれた外来遺伝子を発現する組換えインフルエンザウイルス

\begin{tabular}{l|l|l}
\hline \multicolumn{1}{c|}{ 外来遺伝子 } & \multicolumn{1}{|c}{ 戦 略 } & \multicolumn{1}{|c}{ 参考文献 } \\
\hline HIV-1 Nef & 口蹄疫ウイルス 2A & $54,55)$ \\
CAT & 口蹄疫ウイルス 2A & $21)$ \\
Mycobacterium tuberculosis ESTA-6 & 口蹄疫ウイルス 2A & $56,57)$ \\
Saccharomyces cerevisiae PUT3 & NS1 と融合 & $58)$ \\
Drosophilia melanogaster DmNcd & NS1 融合 & $58)$ \\
GFP & カスパーゼ認識配列 & $20)$ \\
GFP & Stop-Startコドン & $22)$ \\
Human IL-2 & Stop-Startコドン & $22)$ \\
\hline
\end{tabular}

表 5 パッケージングシグナル配列を用いた外来遺伝子導入インフルエンザウイルス

\begin{tabular}{l|l|l}
\hline \multicolumn{1}{c|}{ 外来遺伝子 } & \multicolumn{1}{|c}{ 挿入遺伝子分節 } & 参考文献 \\
\hline GFP & NA & $26)$ \\
GFP & HA & $32)$ \\
vesicular stomatitis virus G & HA & $32)$ \\
Influenza B virus HA, NA & HA, NA & $59)$ \\
GFP & NS & $27)$ \\
GFP & PA, PB1, PB2 & $28)$ \\
GFP & PA, PB1, PB2 & $30)$ \\
Newcastle disease virus HN & NA & $60)$ \\
GFP & HA & $29)$ \\
GFP & NP & $31)$ \\
Influenza C virus HEF & NA & $61)$ \\
\hline
\end{tabular}

(1) NS 分節はインフルエンザウイルスのゲノム 分節のなかで一番小さい $(890 \mathrm{~kb})$ ため, 大きいサイ

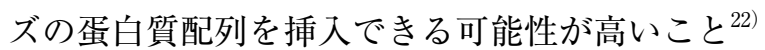

(2) I 型インターフェロンのアンタゴニスト機能 を担うNS1 上のドメインが同定されていること ${ }^{23)}$

(3) NS2 発現に必須な mRNAのスプライシング に影響を与えることなく組換えインフルエンザウイ ルスを構築できること ${ }^{24)}$

(4) NS1 欠損ウイルスが弱毒化された表現型を示 すこと

などによる ${ }^{25)}$.

具体的な戦略としては, NS1 の C 末端に外来性 配列を挿入する方法, カスパーゼ認識配列やNA の場合と同様に FMD 2A を NS1 と外来性蛋白質の 間に挿入し, 宿主細胞内で外来性蛋白質を切断させ る方法, そして B 型インフルエンザウイルスの $\mathrm{M}$ 遺伝子分節にみられる Stop-start コドンを挿入し, bisictronic に外来性遺伝子を発現させる方法が報告 されている.

\section{追加の遺伝子分節を持った} 組換えインフルエンザウイルス

外来性蛋白質遺伝子を組み込んだ分節を 9 本目の RNA 分節をウイルスに持たせることにより, 外来 性遺伝子を発現する組換えインフルエンザウイルス の作製も報告されている ${ }^{17)}$.

Zhou らはブタコレラウイルスの E2 蛋白質の細 胞外領域を HAの膜貫通領域および細胞内領域と 融合させたキメラ蛋白質をコードする分節を 9 本目 とした 9 本鎖ウイルスを作製した ${ }^{18)}$. Strobel らは 9 本目の分節として緑色蛍光蛋白質 (GFP) あるいは メラノーマ由来の腫瘍関連抗原をコードしたウイル スを作製した ${ }^{19)}$.

\section{ゲノムパッケージング配列を用いた外来遺伝子 挿入組換えインフルエンザウイルス}

筆者らは，インフルエンザウイルスの分節が効率 よくウイルス粒子に取り込まれるのには, vRNA の 5'と 3 末端の非翻訳領域配列と翻訳領域の両端の 配列 (ゲノムパッケージング配列) が重要であること 
を明らかにした ${ }^{26,30,32)}$ 。この配列を用いて GFP な どの外来性遺伝子を導入した各ゲノム分節を取り込 ませることが可能になっただけではなく，水疮性口 内炎ウイルスの $\mathrm{G}$ 蛋白質, B 型インフルエンザウ イルスの HA や $\mathrm{NA}$ ，ニューキャッスル病ウイルス の HN 蛋白質，あるいは C 型インフルエンザウイ ルスの hemagglutinin-esterase-fusion (HEF) 蛋白 質を安定的に発現する組換えインフルエンザウイル スが作製された(表 5).

そして, 挿入されたこれらの遺伝子は, 継代を繰 り返しても安定的に発現することが確認されてお り，今後はパッケージングシグナル配列を利用する ことにより遺伝子発現が安定なウイルスベクターが 主流となる可能性が高い.

\section{組換えインフルエンザウイルスを用いた 不活化ワクチン作製}

現行のインフルエンザワクチンは，HA 覀型の異 なるウイルス感染に対する効果はない。つまり, $\mathrm{HA}$ 亜型の異なる新型ウイルスが世界的大流行(パ ンデミック)を引き起こした場合には, 現行ワクチ ンでウイルスの拡がりを抑えることは不可能であ る.

また，たとえ HA 亜型が同じウイルスでも，ヒ トのウイルスと抗原性が大きく異なればパンデミッ クウイルスになりうることが, 2009 年春に突然出 現したブタ由来の新型 H1N1 ウイルスの蔓延によ り証明された。いずれにせよ新型ウイルスが出現し た場合, パンデミックの進行, 規模を抑えるために 予防ワクチンの作製が急務である ${ }^{33)}$.

パンデミックが危惧される H5N1 鳥ウイルスは 高病原性であり, ワクチンの製造基材である発育䳕 卵に接種すると胎児を殺すため高力価で品質のよい ウイルス液が回収できない。 また，ワクチン製造者 に対する安全面からも, 高病原性ウイルスをそのま まワクチン製造株として用いることはできない.

しかし, 現在流行中の H5N1 高病原性ウイルスと 抗原性が合致する低病原性ウイルスは存在しない。 つまり，いずれの自然分離株もワクチン製造株とし て用いることができない.この問題は, リバース
ジェネティクスによる組換えウイルス作製のアプ ローチによって解決された. 流行株と抗原性が同じ で, 発育鶏卵でよく増殖する弱毒ウイルスがワクチ ン製造株として人工的に作製された。つまり，高病 原性 H5N1 ウイルスからクローニングした HA 遺 伝子の病原性に関与する開裂部位コード領域を低病 原性タイプに改変(RERRRKKRから RETRに変 更)した HA 遺伝子と H5N1 流行株からクローニン グした NA 遺伝子を持つ組換えウイルスである.

$\mathrm{HA}, \mathrm{NA}$ 以外の 6 本の遺伝子は䳕卵高増殖性で ある PR8 株(PR8 をドナーウイルスとよぶ) 由来で ある。この組換えウイルスは，ワクチン製造株とし てWHO から推奨されている34). 先進国ではこの組 換えウイルスをもとにした H5N1 プレパンデミッ クワクチンの備蓄が進行中である。 わが国でもワク チン原液がこれまでに 3,000 万人分備蓄されてい る.

一方，実際に H5N1 ウイルスによるパンデミック が発生した場合には，パンデミックウイルスを元に パンデミックワクチンが作製される。しかしなが ら, 通常の季節性ワクチンと比較して, H5N1 ワク チン製造株の鶏卵における増殖性の低さ，ならびに ヒトに対する免疫原性の低さが臨床試験から露見し ており，パンデミックの拡がりを抑えるためには, できる限りのドーズ数のパンデミックワクチンを用 意する必要がある。しかし, 製造会社のワクチン生 産能力には限界があるため, 国内必要ドース数に到 達するのでさえかなりの期間を要することが予想さ れる。つまり，いまの生産量ではワクチンがつくれ ない発展途上国に行き渡る見込みはない.

この状況を克服する一つの方策は，舀卵当たりの ウイルス回収量を増加させワクチンドーズ数を増や すことである，たとえば, WHO が推奨したプレパ ンデミックワクチン製造株 (NIBRG-14 株) は季節性 ワクチン製造株と比較すると, 鷄卵での増殖性が数 段劣る. H5N1 ワクチン製造株のドナーウイルスは PR8 (Cambridge) 株であるが，同じ PR8 株でも継 代歴により増殖性状に随分違いがみられる。たとえ ば，筆者らの研究室で保有している PR8（UW）株を ドナーとして用いると同じ遺伝子組成の製造株の鶏 卵増殖性は 4 倍も上がる ${ }^{35)}$ 。さらに, NA 遺伝子を 


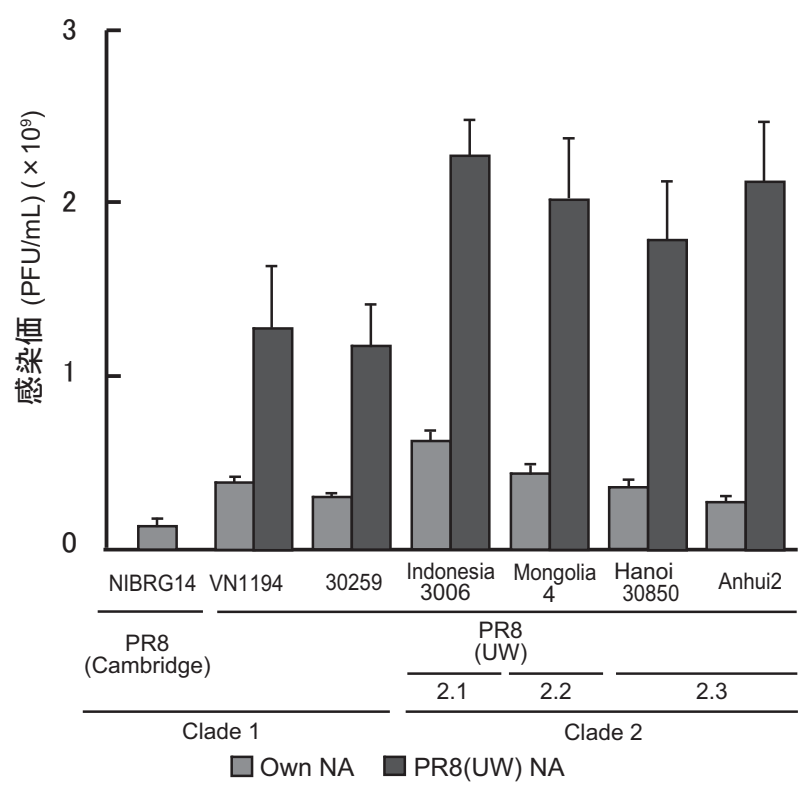

図 3 H5N1 ワクチン製造候補株の発育鷄卵増殖性

PR8(UW) 株をドナーウイルスとする PR8/H5N1 リアソー タントの増殖性をWHO 推奨株 (NIBRG-14) と比較した。 そ れぞれ HA と NA 遺伝子が同一株由来の場合と PR8(UW) 由来の NA を持つ場合の増殖性を調べた。

VN1194(A/Vietnum/1194/04) と 30259(A/Vietnam/30259/04) は, クレード 1, Indonesia3006(A/Indonesia/3006/05) はク レード 2.1, Mongolia4(A/whooper swan/Mongolia/4/05) は, クレード 2.2, Hanoi30850(A/Vietnam/30850/05)と Anhui2(A/Anhui/2/05)はクレード 2.3 に属する. $33^{\circ} \mathrm{C}$ で 48 時間培養後のウイルス感染価をプラック力価で表 示した.

流行株由来から PR8(UW) 株由来のものに置き換え ると，さらに 3 倍上がる．他の分子系統グループ (クレード)に属する分離株での実験でも PR8(UW) のNA を用いたほうが，有意に増殖性が上がる(図 3).

また，入手に困難を来たす発育鶏卵の代替手段と して培養細胞を用いたワクチンの開発が海外を中心 に進展している．培養細胞での増殖にすぐれるド ナーウイルスを用いれば，生産性の高い製造株が作 製できる。たとえば, PR8(UW) 株はPR8(Cambridge)株より Mardin-Darby canine kidney(MDCK) 細胞での増殖性が数段よく, ドナーウイルスとして の活用が充分考えられる.PR8(UW) 株をバックグ ラウンドに持つウイルスで, よりストーク領域の長 いNAに置き換えたり, NS 遺伝子をPR8 (Cambridge) 株と置き換えたりすることでMDCK 細胞での増殖性を高めることができる(図 4) ${ }^{36)}$.

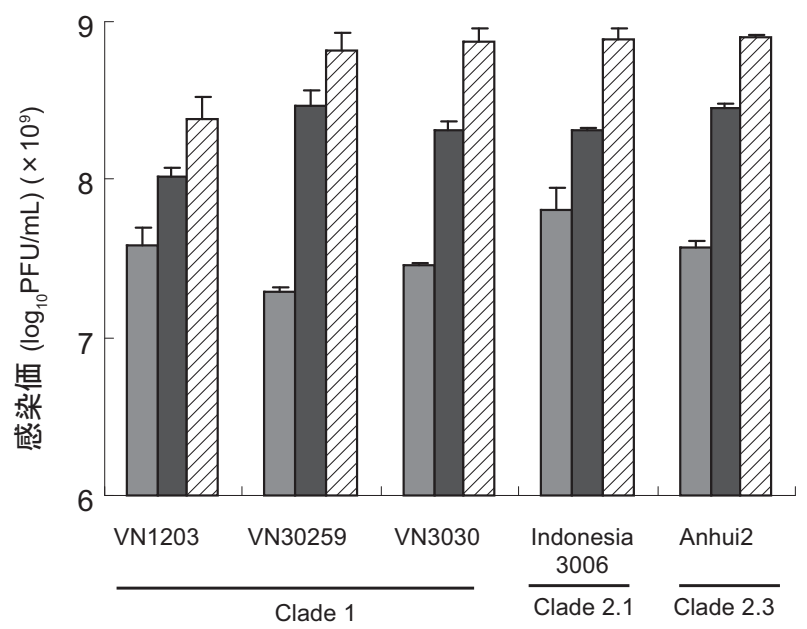

$\square$ Own NA $\square$ Long stalk NA $\square$ Long stalk NA + CamNS

図 4 H5N1 ワクチン製造候補株の MDCK 細胞での増殖性 PR8(UW) 株をドナーウイルスとする組換えワクチン製造株 の MDCK 細胞での増殖性を調べた

それぞれ HA と NA 遺伝子が同一株由来の場合と長い NA を持つ場合, そして NS 遺伝子を PR8(Cambridge) 株の由 来と置き換えた場合のウイルスの増殖性を調べた。

VN1203(A/Vietnum/1194/04) と VN30259(A/Vietnam/30259/ 04), VN3030(A/Vietnam/30259/04) はクレード1, Indonesia3006(A/Indonesia/3006/05) はクレード2.1, Anhui2 (A/Anhui/2/05) はクレード 2.3 に属する.

$33^{\circ} \mathrm{C}$ で 48 時間培養後のウイルス感染価をプラック力価で表 示した.

このように，ワクチン製造株の遺伝子組成を工 夫，変更することにより，抗原性を維持したままワ クチン製造株の発育鷄卵や培養細胞での増殖性を上 昇させることは可能である.

\section{組換えインフルエンザウイルスを用いた 弱毒生ワクチン作製}

リバースジェネティクスにより，いくつかの弱毒 変異ウイルスが作製されている。たとえば，NS1 の C 末欠損ウイルス ${ }^{62)}$, M2 欠損ウイルス ${ }^{63)}$, NA 欠損ウイルス ${ }^{64)}$ などである．野生株とくらべいずれ も弱毒化していること，また生ワクチンとしての免 疫原性も充分であることが動物モデルで示されてい る.

また最近では, microRNA（miRNA）認識配列を ウイルス RNA に導入することで，弱毒化されたウ 
イルスが作製できることが，レンチウイルス，ピコ ルナウイルスやラブドウイルス同様にインフルエン ザウイルスでも報告された ${ }^{65)}$. PR8 株の NP 遺伝子 に miRNA-93 の応答因子を導入したウイルスを作 製し，ヒト細胞株やマウスに接種したところ，野生 型のウイルスよりも増殖が抑えられた。 また miRNA-93 の認識配列を持つ組換えウイルスで免 疫されたマウスは, 野生型の PR8 株や H5N1 ウイ ルス株の攻撃を防御することがわかり, 今後の応用 が期待されている.

\section{おわりに}

インフルエンザウイルスのこれまでの基礎研究の 積み重ねが，リバースジェネテイクスの確立につな がり, その結果, 任意の変異ウイルスを作製するこ とが可能になった。また，この技術は H5N1 ワクチ ン株の作製にも貢献した. 近い将来, インフルエン ザワクチン株はすべてリバースジェネティクスに よって作製されるようになると推測される。これか らも偶発的に出現しつづけるであろう新型インフル エンザをすべからず制圧できるようなユニバーサル ワクチンの開発を期待したい.

一方, リバースジェネテイクスによるウイルス改 変技術は, 今後インフルエンザウイルスをベクター 化する試みにも向けられている，インフルエンザウ イルスの持つ効率のよい感染性をウイルスベクター に応用することにより，これまでにはないユニーク なベクターウイルスの開発が期待される．特に，ほ かのウイルスベクターではカバーできない難治性呼 吸器疾患などに焦点を絞ったインフルエンザベク ター開発は有用であろう。

\section{文 献}

1) Verma I, Weitzman $M:$ Gene therapy : twenty-first century medicine. Annu Rev Biochem 74:711-738, 2005.

2) Luytjes W, Krystal M, Enami M, Parvin J, Palese P : Amplification, expression, and packaging of foreign gene by influenza virus. Cell $59: 1107-1113,1989$.

3) Neumann G, Watanabe T, Ito H, Watanabe S, Goto H et al. : Generation of influenza A viruses entirely from cloned cDNAs. Proc Natl Acad Sci U S A 96 : 9345-9350, 1999.

4) Fodor E, Devenish L, Engelhardt OG, Palese P, Brownlee GG et al. : Rescue of influenza A virus from recombinant DNA. J Virol $73:$ 9679-9682, 1999.
5) Hoffmann E, Neumann G, Kawaoka Y, Hobom G, Webster $\mathrm{R}$ : A DNA transfection system for generation of influenza A virus from eight plasmids. Proc Natl Acad Sci U S A $97: 6108-6113,2000$.

6) Neumann G, Fujii K, Kino Y, Kawaoka Y : An improved reverse genetics system for influenza $A$ virus generation and its implications for vaccine production. Proc Natl Acad Sci U S A 102 : 16825-16829, 2005.

7) de Wit E, Spronken MI, Vervaet G, Rimmelzwaan GF, Osterhaus AD et al. : A reverse-genetics system for Influenza A virus using T7 RNA polymerase. J Gen Virol 88 : 1281-1287, 2007.

8) Li Z, Mueller SN, Ye L, Bu Z, Yang C et al. : Chimeric influenza virus hemagglutinin proteins containing large domains of the Bacillus anthracis protective antigen : protein characterization, incorporation into infectious influenza viruses, and antigenicity. J Virol $79: 10003-10012,2005$.

9) Machado A, Naffakh N, van der Werf S, Escriou N : Expression of a foreign gene by stable recombinant influenza viruses harboring a dicistronic genomic segment with an internal promoter. Virology $313: 235-249,2003$.

10) Vieira Machado A, Naffakh N, Gerbaud S, van der Werf S, Escriou N : Recombinant influenza A viruses harboring optimized dicistronic NA segment with an extended native 5' terminal sequence : induction of heterospecific $\mathrm{B}$ and $\mathrm{T}$ cell responses in mice. Virology $345: 73-87,2006$.

11) García-Sastre A, Muster T, Barclay W, Percy N, Palese P : Use of a mammalian internal ribosomal entry site element for expression of a foreign protein by a transfectant influenza virus. J Virol $68: 6254-6261,1994$.

12) Restifo N, Surman DR, Zheng H, Palese P, Rosenberg SA et al. : Transfectant influenza A viruses are effective recombinant immunogens in the treatment of experimental cancer. Virology $249: 89-97,1998$.

13) Miyahira Y, García-Sastre A, Rodriguez D, Rodriguez JR, Murata $\mathrm{K}$ et al. : Recombinant viruses expressing a human malaria antigen can elicit potentially protective immune CD8+ responses in mice. Proc Natl Acad Sci U S A 95 : 3954-3959, 1998.

14) Nakaya Y, Nakaya T, Park MS, Cros J, Imanishi J et al. : Induction of cellular immune responses to simian immunodeficiency virus gag by two recombinant negative-strand RNA virus vectors. J Virol $78:$ 9366-9375, 2004.

15) Nakaya $Y$, Zheng H, García-Sastre A : Enhanced cellular immune responses to SIV Gag by immunization with influenza and vaccinia virus recombinants. Vaccine $21: 2097-$ 2106, 2003.

16) Percy N, Barclay W, García-Sastre A, Palese P : Expression of a foreign protein by influenza A virus. J Virol 68 : 4486-4492, 1994.

17) Enami M, Sharma G, Benham C, Palese P : An influenza virus containing nine different RNA segments. Virology 185 : 291-298, 1991.

18) Zhou Y, König M, Hobom G, Neumeier E : Membrane-anchored incorporation of a foreign protein in recombinant influenza virions. Virology $246: 83-94,1998$.

19) Strobel I, Krumbholz M, Menke A, Hoffmann E, Dunbar PR et al. : Efficient expression of the tumor-associated antigen MAGE-3 in human dendritic cells, using an avian influenza virus vector. Hum Gene Ther $11: 2207-2218,2000$.

20) Kittel C, Sereinig S, Ferko B, Stasakova J, Romanova J et al. : Rescue of influenza virus expressing GFP from the NS1 reading frame. Virology $324: 67-73,2004$.

21) Takasuka N, Enami M, Itamura $S$, Takemori $T$ : Intranasal inoculation of a recombinant influenza virus containing exogenous nucleotides in the NS segment induces mucosal immune response against the exogenous gene product in 
mice. Vaccine $20: 1579-1585,2002$

22) Kittel C, Ferko B, Kurz M, Voglauer R, Sereinig S et al. : Generation of an influenza A virus vector expressing biologically active human interleukin-2 from the NS gene segment. J Virol $79:$ 10672-10677, 2005.

23) Lin D, Lan J, Zhang $Z$ : Structure and function of the NS1 protein of influenza A virus. Acta Biochim Biophys Sin (Shanghai) $39:$ 155-162, 2007.

24) García-Sastre A, Egorov A, Matassov D, Brandt S, Levy $\mathrm{DE}$ et al. : Influenza A virus lacking the NS1 gene replicates in interferon-deficient systems. Virology $252: 324-$ 330, 1998.

25) Talon J, Salvatore M, O'Neill RE, Nakaya Y, Zheng H et al. : Influenza A and B viruses expressing altered NS1 proteins: A vaccine approach. Proc Natl Acad Sci U S A $97:$ 4309-4314, 2000.

26) Fujii $Y$, Goto H, Watanabe $T$, Yoshida T, Kawaoka Y : Selective incorporation of influenza virus RNA segments into virions. Proc Natl Acad Sci U S A 100 : 2002-2007, 2003.

27) Fujii K, Fujii Y, Noda T, Muramoto Y, Watanabe T et al. : Importance of both the coding and the segment-specific noncoding regions of the influenza A virus NS segment for its efficient incorporation into virions. J Virol $79: 3766-$ $3774,2005$.

28) Liang $Y$, Hong $Y$, Parslow $T$ : cis-Acting packaging signals in the influenza virus PB1, PB2, and PA genomic RNA segments. J Virol $79:$ 10348-10355, 2005.

29) Marsh G, Hatami R, Palese P : Specific residues of the influenza A virus hemagglutinin viral RNA are important for efficient packaging into budding virions. J Virol 81 : 97279736, 2007.

30) Muramoto Y, Takada A, Fujii K, Noda T, Iwatsuki-Horimoto $\mathrm{K}$ et al. : Hierarchy among viral RNA (vRNA) segments in their role in vRNA incorporation into influenza $A$ virions. J Virol $80: 2318-2325,2006$.

31) Ozawa M, Fujii K, Muramoto Y, Yamada S, Yamayoshi S et al. : Contributions of two nuclear localization signals of influenza A virus nucleoprotein to viral replication. J Virol $81: 30-41,2007$

32) Watanabe T, Watanabe S, Noda T, Fujii Y, Kawaoka Y : Exploitation of nucleic acid packaging signals to generate a novel influenza virus-based vector stably expressing two foreign genes. J Virol $77:$ 10575-10583, 2003.

33) Horimoto $T$, Kawaoka $Y$ : Influenza : lessons from past pandemics, warnings from current incidents. Nat Rev Microbiol 3:591-600, 2005.

34) Wood J, Robertson J : From lethal virus to life-saving vaccine : developing inactivated vaccines for pandemic influenza. Nat Rev Microbiol 2: 842-847, 2004.

35) Horimoto T, Murakami S, Muramoto Y, Yamada S, Fujii K et al. : Enhanced growth of seed viruses for H5N1 influenza vaccines. Virology $366: 23-27,2007$.

36) Murakami S, Horimoto T, Yamada S, Kakugawa S, Goto H et al. : Growth determinants for H5N1 influenza vaccine seed viruses in MDCK cells. J Virol $82: 10502-10509$, 2008.

37) Rodrigues M, Li S, Murata K, Rodriguez D, Rodriguez JR et al. : Influenza and vaccinia viruses expressing malaria $\mathrm{CD} 8+\mathrm{T}$ and $\mathrm{B}$ cell epitopes. Comparison of their immunogenicity and capacity to induce protective immunity. J Immunol $153: 4636-4648,1994$.

38) Li S, Polonis V, Isobe H, Zaghouani H, Guinea R et al. : Chimeric influenza virus induces neutralizing antibodies and cytotoxic $\mathrm{T}$ cells against human immunodeficiency virus type 1. J Virol 67:6659-6666, 1993.

39) Gonzalo R, Rodríguez D, García-Sastr A, Rodríguez JR, Palese $\mathrm{P}$ et al. : Enhanced CD8+ $\mathrm{T}$ cell response to HIV-1 env by combined immunization with influenza and vaccinia virus recombinants. Vaccine $17: 887-892,1999$.

40) Muster T, Guinea R, Trkola A, Purtscher M, Klima A et al. : Cross-neutralizing activity against divergent human immunodeficiency virus type 1 isolates induced by the gp41 sequence ELDKWAS. J Virol 68 : 4031-4034, 1994.

41) Muster T, Ferko B, Klima A, Purtscher M, Trkola A et al. : Mucosal model of immunization against human immunodeficiency virus type 1 with a chimeric influenza virus. J Virol $69: 6678-6686,1995$.

42) Gherardi M, Nájera JL, Pérez-Jiménez E, Guerra S, GarcíaSastre A et al. : Prime-boost immunization schedules based on influenza virus and vaccinia virus vectors potentiate cellular immune responses against human immunodeficiency virus Env protein systemically and in the genitorectal draining lymph nodes. J Virol $77: 7048-7057,2003$.

43) Staczek J, Gilleland HE Jr, Gilleland LB, Harty RN, GarcíaSastre A et al. : A chimeric influenza virus expressing an epitope of outer membrane protein $\mathrm{F}$ of Pseudomonas aeruginosa affords protection against challenge with $\mathrm{P}$. aeruginosa in a murine model of chronic pulmonary infection. Infect Immun $66:$ 3990-3994, 1998.

44) Thomas P, Brown SA, Yue W, So J, Webby RJ et al. : An unexpected antibody response to an engineered influenza virus modifies CD8+ T cell responses. Proc Natl Acad Sci U S A $103: 2764-2769,2006$.

45) Isobe H, Moran T, Li S, Young A, Nathenson S et al. : Presentation by a major histocompatibility complex class I molecule of nucleoprotein peptide expressed in two different genes of an influenza virus transfectant. J Exp Med 181 : 203-213, 1995.

46) Murata K, García-Sastre A, Tsuji M, Rodrigues M, Rodriguez $\mathrm{D}$ et al. : Characterization of in vivo primary and secondary CD8 $+\mathrm{T}$ cell responses induced by recombinant influenza and vaccinia viruses. Cell Immunol $173: 96-107$, 1996.

47) Castrucci M, Bilsel P, Kawaoka Y : Attenuation of influenza $A$ virus by insertion of a foreign epitope into the neuraminidase. J Virol $66: 4647-4653,1992$.

48) González-Aseguinolaza G, Nakaya Y, Molano A, Dy E, Esteban $\mathrm{M}$ et al. : Induction of protective immunity against malaria by priming-boosting immunization with recombinant cold-adapted influenza and modified vaccinia Ankara viruses expressing a CD8+-T-cell epitope derived from the circumsporozoite protein of Plasmodium yoelii. J Virol 77 ; 11859-11866, 2003.

49) Castrucci M, Hou S, Doherty P, Kawaoka Y : Protection against lethal lymphocytic choriomeningitis virus (LCMV) infection by immunization of mice with an influenza virus containing an LCMV epitope recognized by cytotoxic T lymphocytes. J Virol $68: 3486-3490,1994$.

50) Mueller S, Renard A, Boato F, Vogel, D, Naegeli M et al. : The early expression of glycoprotein $\mathrm{B}$ from herpes simplex virus can be detected by antigen-specific $\mathrm{CD} 8+\mathrm{T}$ cells. $\mathrm{J}$ Virol $77: 2445-2451,2003$.

51) Efferson C, Schickli J, Ko BK, Kawano K, Mouzi S et al. : Activation of tumor antigen-specific cytotoxic $\mathrm{T}$ lymphocytes (CTLs) by human dendritic cells infected with an attenuated influenza A virus expressing a CTL epitope derived from the HER-2/neu proto-oncogene. J Virol 77 : 7411-7424, 2003.

52) He Q, Martinez-Sobrido L, Eko FO, Palese P, Garcia-Sastre A et al. : Live-attenuated influenza viruses as delivery vectors for Chlamydia vaccines. Immunology $122: 28-37$, 2007.

53) Blaney JJ, Nobusawa E, Brehm MA, Bonneau RH, Mylin LM et al. : Immunization with a single major histocompati- 
bility complex class I-restricted cytotoxic T-lymphocyte recognition epitope of herpes simplex virus type 2 confers protective immunity. J Virol 72:9567-9574, 1998.

54) Ferko B, Stasakova J, Sereinig S, Romanova J, Katinger D et al. : Hyperattenuated recombinant influenza A virus nonstructural-protein-encoding vectors induce human immunodeficiency virus type $1 \mathrm{Nef}-$ specific systemic and mucosal immune responses in mice. J Virol $75: 8899-8908,2001$.

55) Ferko B, Stasakova J, Romanova J, Kittel C, Sereinig S et al. : Immunogenicity and protection efficacy of replicationdeficient influenza A viruses with altered NS1 genes. J Virol $78: 13037-13045,2004$.

56) Stukova M, Sereinig S, Zabolotnyh NV, Ferko B, Kittel C et al. : Vaccine potential of influenza vectors expressing Mycobacterium tuberculosis ESAT-6 protein. Tuberculosis (Edinb) $86: 236-246,2006$.

57) Sereinig S, Stukova M, Zabolotnyh N, Ferko B, Kittel C et al. : Influenza virus NS vectors expressing the mycobacterium tuberculosis ESAT- 6 protein induce CD4+ Th1 immune response and protect animals against tuberculosis challenge. Clin Vaccine Immunol $13:$ 898-904, 2006.

58) Wang X, Basler CF, Williams BR, Silverman RH, Palese P et al. : Functional replacement of the carboxy-terminal twothirds of the influenza A virus NS1 protein with short heterologous dimerization domains. J Virol 76 : 12951-12962, 2002.
59) Horimoto $\mathrm{T}$, Takada A, Iwatsuki-Horimoto $\mathrm{K}$, Hatta $\mathrm{M}$, Goto $\mathrm{H}$ et al. : Generation of influenza A viruses with chimeric (type A/B) hemagglutinins. J Virol $77: 8031-8038$, 2003.

60) Park M, Steel J, García-Sastre A, Swayne D, Palese P : Engineered viral vaccine constructs with dual specificity : avian influenza and Newcastle disease. Proc Natl Acad Sci U S A $103: 8203-8208,2006$.

61) Gao QS, Brydon EWA, Palese P : A seven-segmented influenza A virus expressing the influenza $C$ virus glycoprotein HEF. J Virol $82: 6419-6426,2008$.

62) Watanabe T, Watanabe S, Kim JH, Hatta M, Kawaoka Y : Novel approach to the development of effective H5N1 influenza A virus vaccines : use of M2 cytoplasmic tail mutants. J Virol $82: 2486-2492,2008$.

63) Falcón AM, Fernandez-Sesma A, Nakaya Y, Moran TM et al. : Attenuation and immunogenicity in mice of temperature-sensitive influenza viruses expressing truncated NS1 proteins. J Gen Virol $86: 2817-2821,2005$.

64) Shinya K, Fujii Y, Ito H, Ito T, Kawaoka Y : Characterization of a neuraminidase-deficient influenza a virus as a potential gene delivery vector and a live vaccine. J Virol $78: 3083-3088,2004$.

65) Perez JT, Pham AM, Lorini MH, Chua MA, Steel J et al. : MicroRNA-mediated species-specific attenuation of influenza A virus. Nat Biotechnol 27 : 572-576, 2009. 